\title{
Diafiltration Based Cow's Milk Partial Demineralization by Membrane Filtration Process - Parameter and Technology Estimations
}

\author{
Attila CSIGHY*, ANDras Koris, GyUla VATAI
}

\begin{abstract}
Milk and dairy products contain a number of biological materials that are essential for the human body, for example proteins, lipids, vitamins and minerals. In this study the application of membrane filtration based milk partial demineralization is detailed. The main point of the partial demineralization is to reduce the monovalent ions $\left(\mathrm{Na}^{+}, \mathrm{K}^{+}\right)$but to keep the divalent ions $\left(\mathrm{Ca}^{2+}, \mathrm{Mg}^{2+}\right)$ content. The experiments were carried out using laboratory ultra- and nanofiltration units. Comparing the separation behavior of the membranes it was found that the investigated membranes are suitable for the partial demineralization. The result of the Lowry test showed that the protein concentration is higher in the retentates of all membrane filtrations than in the permeates.
\end{abstract}

Keywords: partial demineralization of milk, membrane separation, protein concentration, conductivity

\section{Introduction}

The milk is a complex lipid, carbohydrate and protein matrix which contains a number of biologically active components (Csapo, Csapone, 2002). Developments in the filtration technology have created the opportunity for an entirely new approach to partial milk demineralization. Among the most common procedures for demineralization we find ion exchange-based, nanofiltration and electrodialysis-based technologies. Depending on the pore size we can distinguish four types of filtration membranes, namely microfiltration, ultrafiltration, nanofiltration and reverse osmosis. The membrane is a selective barrier which allows some components to pass through but not others. The pore size of an ultrafiltration membrane varies between 10 and $100 \mathrm{~nm}$, these pores are

\footnotetext{
* Corresponding author. E-mail: csighy.attila@gmail.com

Szent István University, Faculty of Food Science, Department of Food Engineering, Menesi út 44, H-1118 Budapest, Hungary
} 
only permeable for the water, salts and the lower molecular weight components. The nanofiltration membranes pore size is between 1 and 10 $\mathrm{nm}$, smaller than that of the ultrafiltration and microfiltration membranes. Nanofiltration membranes are widely used in the dairy industry and the partial demineralization (Baker, Martin, 2007; Suárez et.al. 2009). The membrane separation processes are selective and during the separation chemical changes do not happen, nonetheless, the membrane filtration techniques have disadvantages, such as concentration polarization and membrane fouling, which can result in flux decrease (Mulder, 1996; Strathmann et.al. 2006). To reduce the membrane fouling it is necessary to optimize the transmembrane pressure and the cross-flow velocity, or to use some other turbulence promoters like vibrating modules (Hodúr et.al. 2013) or static mixers (Gáspár, 2016; Nath et.al. 2017). The UF membranes are suitable to separate proteins from sugars and minerals, as it is planned in the first step. The demineralization of whey can be very efficient, when the nanofiltration is followed by a batch diafiltration step.

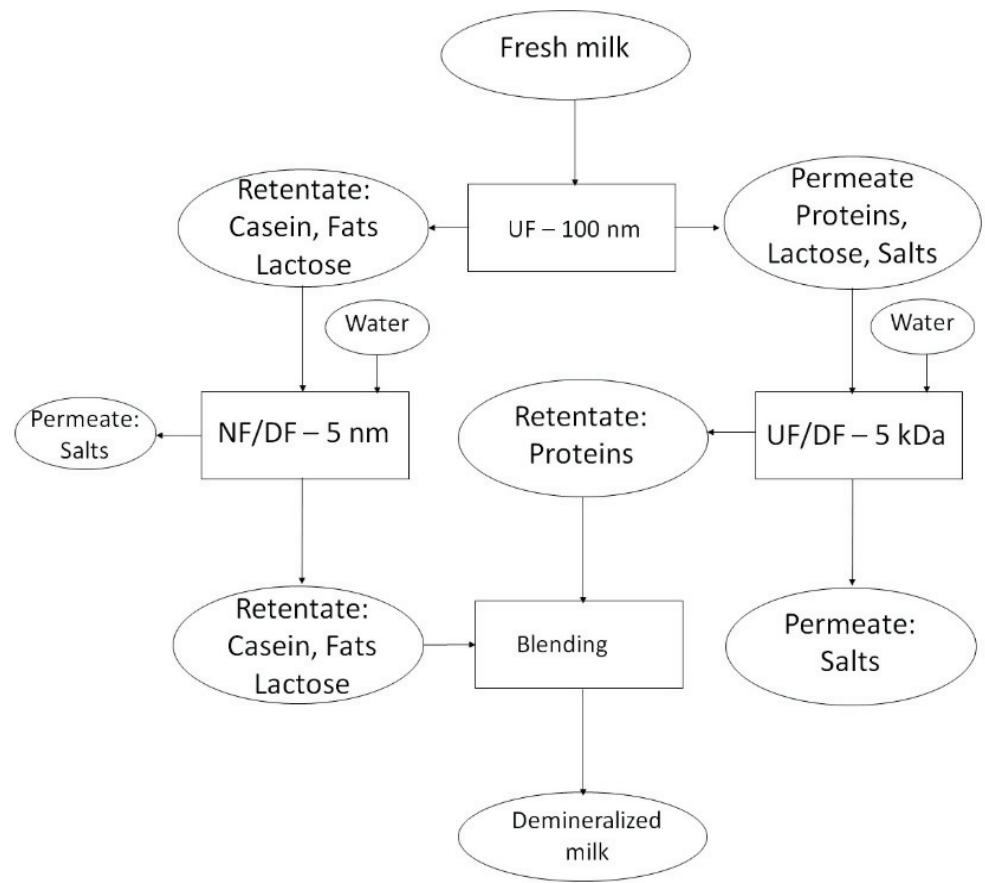

Fig. 1. Flow diagram of milk partial demineralization by using UF and NF membrane diafiltration 
These advantages were observed in ricotta cheese production technology, improving characteristics like color, rheology, microstructure, etc, while the protein and total solids (TS) content did not change (Prudencio et al. 2014; Mohammad et al. 2015). In this study membrane filtration (UF, NF) combining common batch concentration and diafiltration has been carried out for milk partial demineralization using our previous laboratory experiences in demineralization of whey (Román 2010).

The major purpose of this study is the partial demineralization of milk to decrease the monovalent ions from the matrix. To remove the monovalent ions complex membrane separation processes were used as it is presented in the flow diagram in Fig. 1.

The main idea was to separate casein and fats from the proteins, salts and lactose treating the retentate of large pore size UF membrane with the 5 $\mathrm{nm}$ pore size NF membrane washing out the monovalent salts by dialization solvent.

On the other hand, the permeate of the UF was diafiltered using a small nominal molecular weight cut-off (NMWCO) UF membrane to wash out the salts from the permeate.

\section{Material and Methods}

For the experiment the average composition milk was purchased in the local supermarket. In this study two ultrafiltration and one nanofiltration membranes were used. The first ultrafiltration membrane (Schumasiv 100nm, UF1) was used for milk pre-concentration. The next steps were the UF1 permeate and UF1 retentate diafiltration by using different pore size membranes, Schumasiv type $5 \mathrm{~nm}$ pore size nanofiltration membrane for treatment of the UF1 retentate and the Membralox type $5 \mathrm{kDa}$, exactly a small pore size ultrafiltration membrane was used for diafiltration of the UF1 permeate.

For the characterization of the membrane filtration and diafiltration the usual procedure has been used, the permeate flux was calculated from the permeate volume:

$$
J=\frac{V}{A * t}
$$

where $J$ - pure water flux $\left[\mathrm{L} /\left(\mathrm{m}^{2 *} \mathrm{~h}\right)\right], V$ - volume $\left(\mathrm{m}^{3}\right), A$ - membrane surface $\left(\mathrm{m}^{2}\right)$ and $t$ - filtration time $(\mathrm{h})$.

The Volume Concentration ratio (VCR) was calculated as follows: 


\section{$\mathrm{VCR}=\mathrm{Vf} / \mathrm{Vc}$}

where Vf - volume of feed $\left(\mathrm{cm}^{3}\right)$ and Vc - volume of retentate $\left(\mathrm{cm}^{3}\right)$.

The rejection coefficient of certain solutes was calculated using the formula:

$$
\mathrm{RF}=(1-\mathrm{Cp} / \mathrm{Cr})^{*} 100
$$

where $\mathrm{Cp}$ - solute concentration in the permeate $(\mathrm{g} / \mathrm{l})$ and $\mathrm{Cr}$ - solute concentration in the retentate $(\mathrm{g} / \mathrm{l})$.

In the Ultrafiltration of Milk, the effective area of the UF1 ultrafiltration membrane was $0.005 \mathrm{~m}^{2}$. During the experiment the milk was circulated from a feed tank, and the experiment was performed at room temperature $\left(25^{\circ} \mathrm{C}\right)$, which was maintained by using a thermostat bath. The volume of permeate and the time were measured during the experiment. In this experiment the transmembrane pressure was 1.5 bar and the recirculation flow rate was 150 $1 / h$, chosen on the basis of earlier experiments (Csighy et.al. 2016). These parameters were controlled by regulation valves. The protein content in the UF1 permeate and in the UF1 concentrate fractions were determined by taking samples from these fractions during the experimental runs, which were analyzed by LOWRY method.

In the Diafiltration of UF1 permeate (UF/DF), the active area of the membrane was $0.005 \mathrm{~m}^{2}$. The experiment was performed at room temperature $\left(25^{\circ} \mathrm{C}\right)$, which was maintained by using a thermostat bath. During the experiment the transmembrane pressure was 4 bar and the recirculation flow rate was $200 \mathrm{l} / \mathrm{h}$. To control the process parameters, regulation valve and adjustable circulation pump were used.

During the Diafiltration of UF1 retentate (NF/DF), the experiment was carried out at the optimal transmembrane pressure and recirculation flow rate values. In this case these parameters were the same as in the case of the diafiltration of UF1 permeate (4 bar, $200 \mathrm{l} / \mathrm{h}$ ). As a result of this, the process time was reduced significantly and better mixing effect was achieved. The active area of the membrane was $0.005 \mathrm{~m}^{2}$ and the temperature was $25^{\circ} \mathrm{C}$.

The ion content in the permeate and in the retentate fractions were determined by taking samples from these fractions during the experimental runs, which were analyzed by conductivity method. During the ultrafiltration and diafiltration processes the ion content is somehow related to the ion concentration, which is based on the anion and cation concentration, but when we are washing out the cations and/or anions by diafiltration, it can be detected by changing in the conductivity in the permeate and/or retentate (Román, 2010). In order to determine the optimal 
parameters for the membrane separation processes (pre-concentration, diafiltration) it was important to prepare the factorial experimental design. These settings and the results of this and experiments are presented in details elsewhere (Csighy, 2015), but for the experimental runs with different membranes, the optimal transmembrane pressure and recirculation flowrate values were used.

\section{Results and Discussion}

Ultrafiltration of milk. The influence of the volume concentration ratio (VCR) at optimal operation parameters settings during the experimental runs of milk ultrafiltration (UF1) and diafiltration steps of the UF1 permeate and retentate are shown in Figs 2-4, for different membranes. From these results it is obvious that in all cases the measured fluxes are economically feasible, because in the whole range of the experiments, the permeate fluxes are over $20 \mathrm{l} /\left(\mathrm{m}^{2} \mathrm{~h}\right)$ (Mulder, 1996). The volume concentration factor (VCR) and flow rate significantly influenced the permeate flux. Reaching the target volume concentration ratio value $(\mathrm{VCR}=2)$ the flux becomes permanently constant.

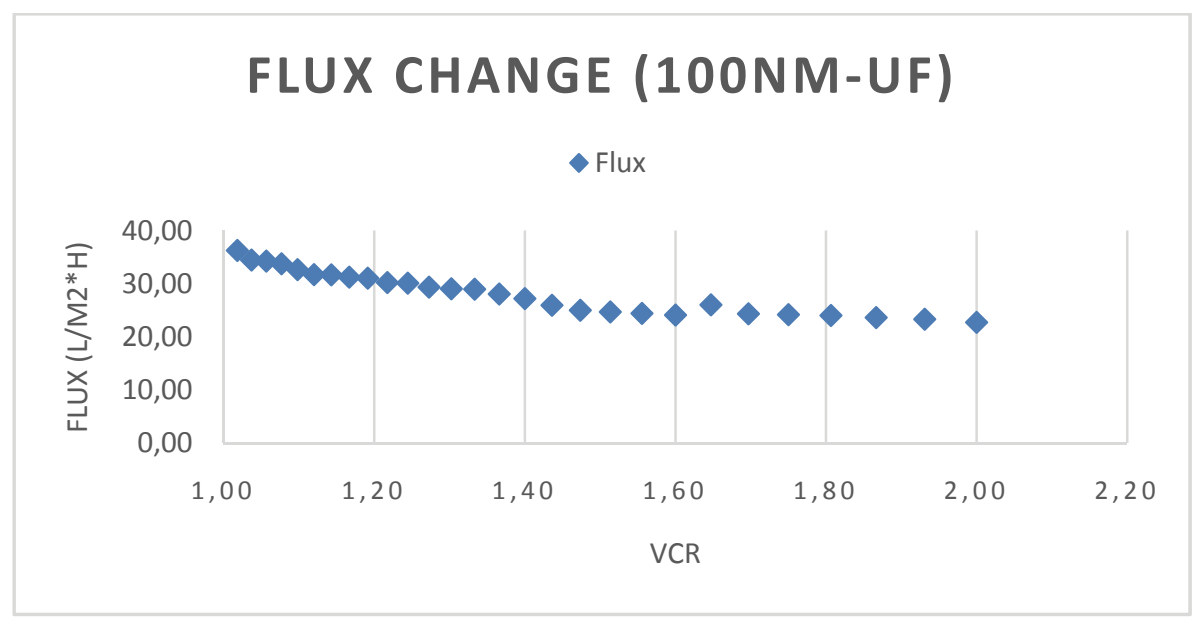

Fig. 2. Milk concentration by ultrafiltration - UF1 (100 nm) membrane

Concentration of UF1 permeate by diafiltration (UF/DF). The small pore size ultrafiltration membrane was used for the elimination of the 
monovalent ions from the UF1 permeate. The membrane had lower pore size $(5 \mathrm{kDa})$ where the macromolecules like proteins and partially the lactose were rejected. The influence of the volume concentration ratio on permeate flux during the diafiltration of UF1 milk permeate is shown in Fig. 3. During the ultrafiltration process the flux was decreasing similarly as in the UF1 ultrafiltration process.

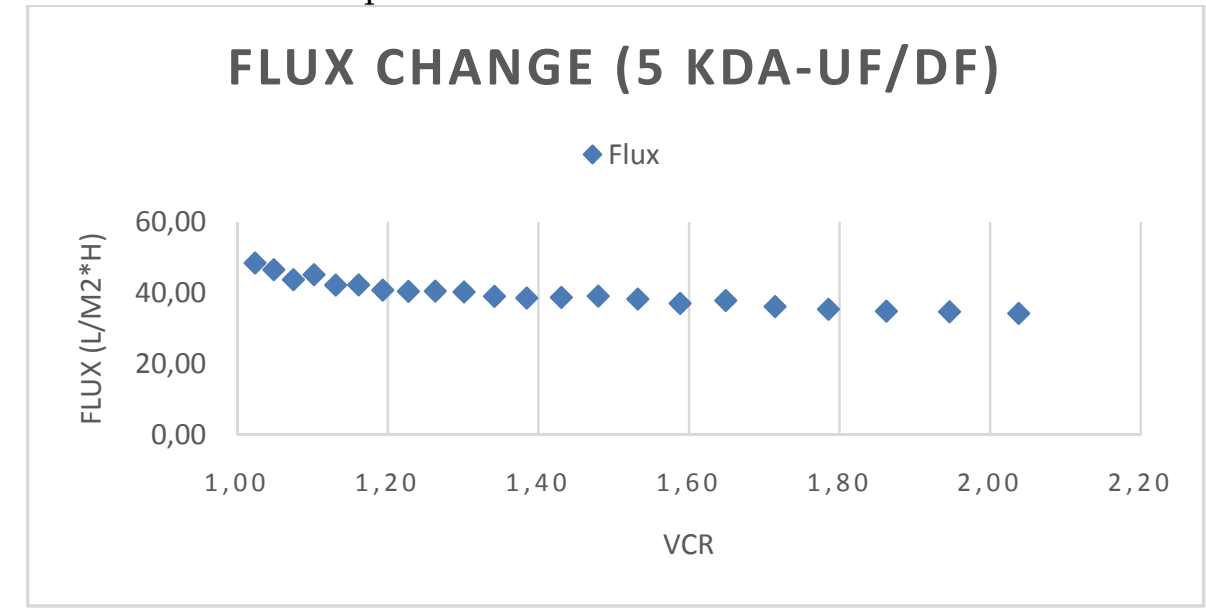

Fig. 3. Concentration of ultrafiltration permeate (UF1) by diafiltration $(5 \mathrm{kDa})$ membrane

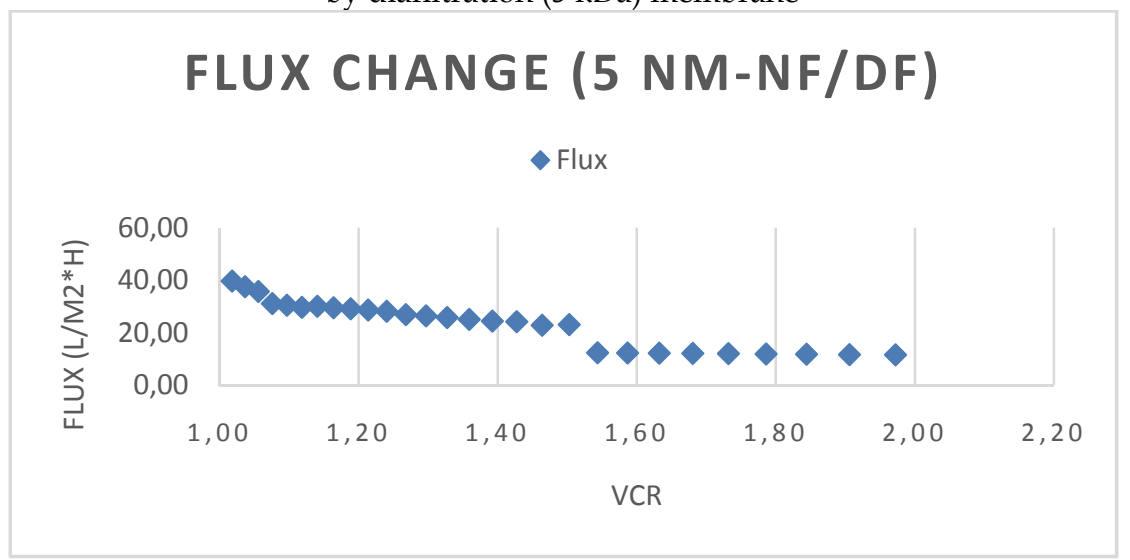

Fig. 4. Concentration of ultrafiltration (UF1) retentate by diafiltration ( $5 \mathrm{~nm}$ ) membrane

Concentration of ultrafiltration (UF1) retentate by diafiltration (NF/DF). As in the case of diafiltration of milk permeate the flux of the permeate also decreased with an increase of the VCR as it is shown in Fig. 4. During the diafiltration of retentate the nanofiltration membrane pore size was $5 \mathrm{~nm}$. 


\section{CONDUCTIVITY (100NM-UF)}

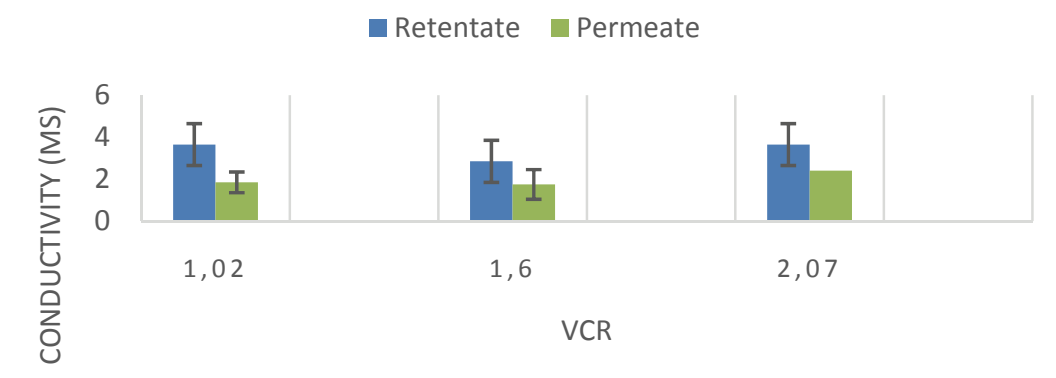

Fig. 5. Conductivity in the UF1 permeate and retentate (UF $100 \mathrm{~nm}$ )

The effect of membrane filtration and diafiltration on the conductivity can be seen in Figs 5-7. During the first ultrafiltration process (UF1) the permeate side of conductivity values are lower than the retentate side values. The average value of conductivity in the permeate was $1.7 \mathrm{mS}$ and 3.7 in the retentate. Therefore the ultrafiltration is a useful method for reducing ion content in the permeate.

During diafiltration stage $(5 \mathrm{kDa})$ the process showed a decreased trend, furthermore this trend is minimal in the target value $(\mathrm{VCR}=2)$ linearly as it is illustrated in Fig. 6. This inverse proportion can be seen in these diafiltration $(5 \mathrm{kDa})$ experiments. The permeate values are decreasing continuously, but the retentate side values are growing.

\section{CONDUCTIVITY (5 KDA-UF/DF)}

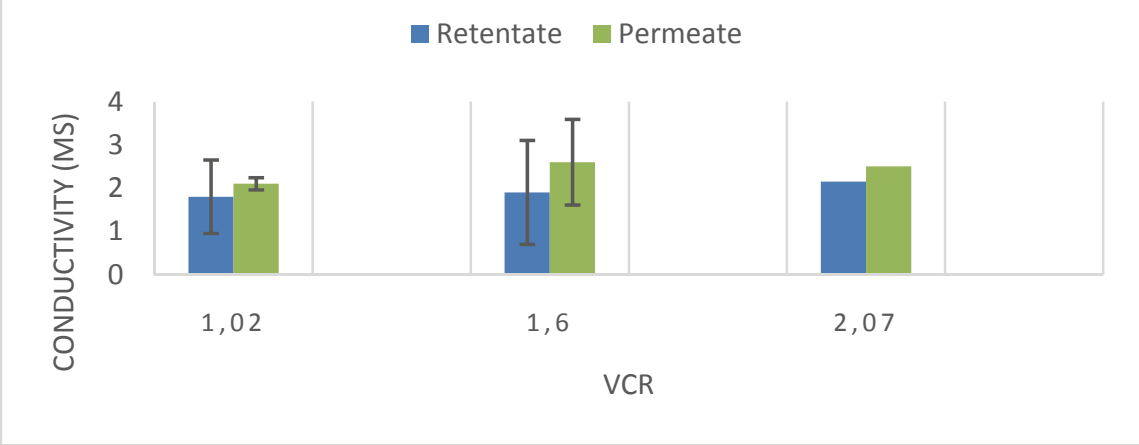

Fig. 6. Conductivity in the permeate and the retentate in UF/DF (5 kDa) It can be seen that the conductivity during the diafiltration process $(5 \mathrm{~nm})$ is decreasing both in the permeate and the retentate. 
The effect of diafiltration (retentate) on the conductivity can be seen in Fig. 7. In the third point the retentate and permeate values become nearly constant, which are $1.5 \mathrm{mS}$ (retentate) and $1 \mathrm{mS}$ (permeate).

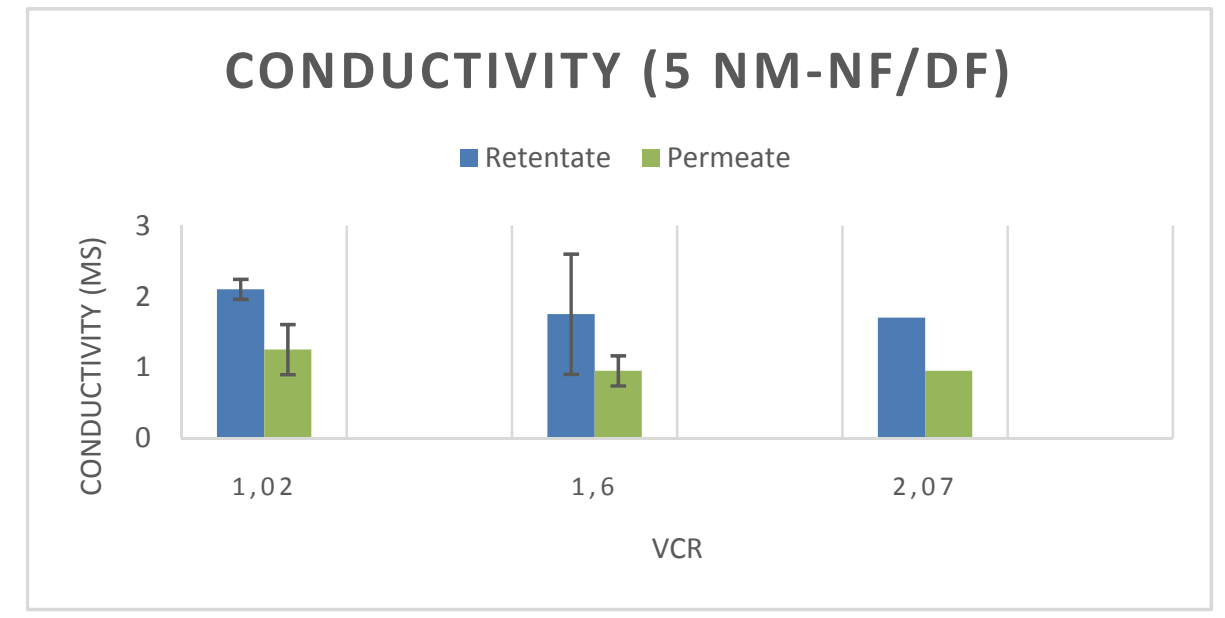

Fig. 7. Conductivity in the permeate and the retentate in NF/DF (5 nm)

The effect of membrane filtration and diafiltration on the protein concentrations in the permeates and retentates are shown in Figs 8 and 9.

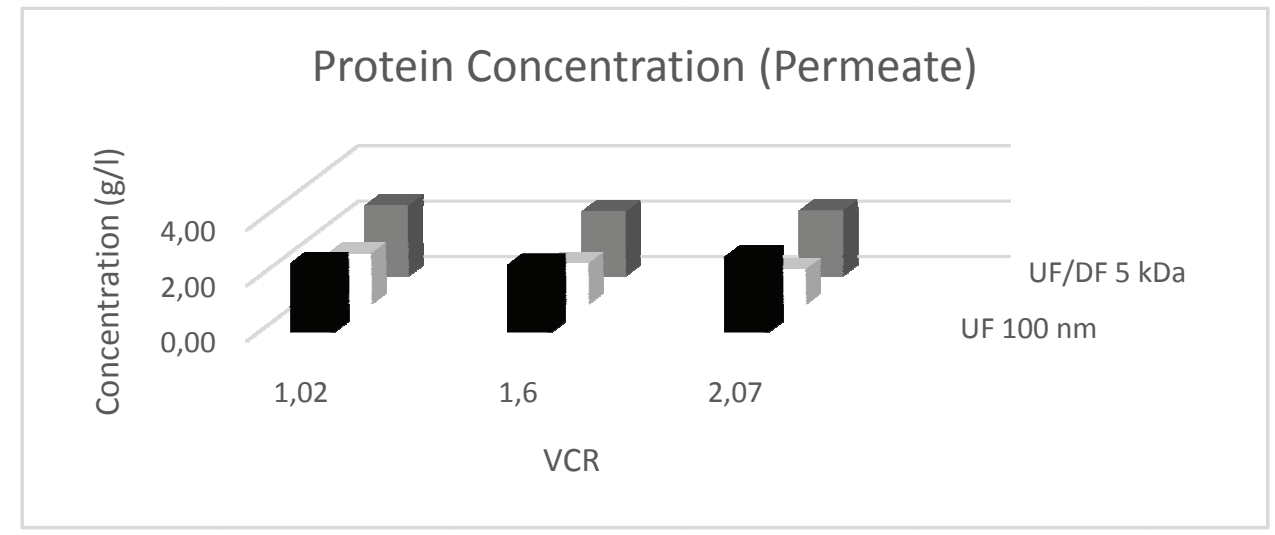

Fig. 8. Protein concentration changes in the permeates in the case of all applied membrane filtration processes 


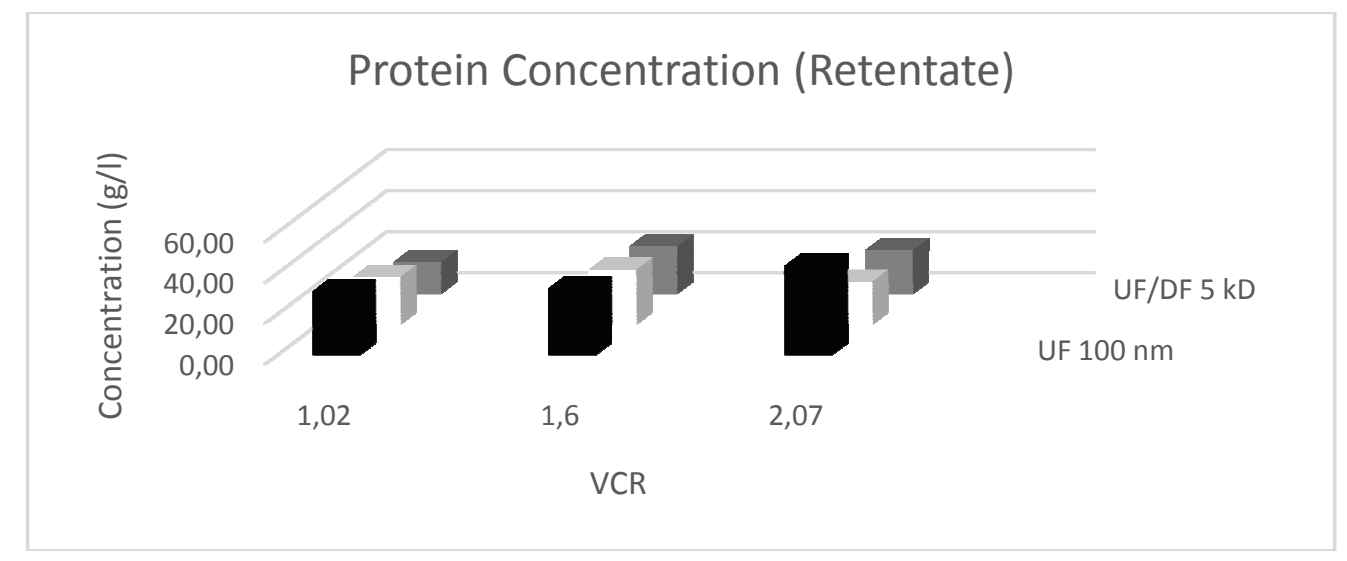

Fig. 9. Protein concentration changes in the retentates in the case of all applied membrane filtration processes

On the basis of the diagrams it is obvious that the proposed multistep membrane technology is suitable for partial demineralization of milk, because the protein concentrations are quite low in the permeates (Fig. 8), between 1 and $2.2 \mathrm{~g} / \mathrm{l}$, even at highest VCR values (2.07), which means that the protein losses during the UF1 concentration step and diafiltration steps are less than $10 \%$, because of good average protein retention $(90 \%)$ of all membranes (Csighy, 2015).

\section{Conclusions}

From the results of the experiments it can be concluded that the first step ultrafiltration (UF1) and also the diafiltration of the UF1 permeate and retentate by ultrafiltration and nanofiltration can be successfully achieved by the investigated membranes (100 nm UF, 5nm NF, $5 \mathrm{kDa} U$ UF). The protein rejection of the membranes (100 nm UF, $5 \mathrm{~nm} \mathrm{NF}, 5 \mathrm{kDa} N F$ ) reached $83-98 \%$, the flux in the end of the process was between 11.5-33 $1 /\left(\mathrm{m}^{2} \mathrm{~h}\right)$. The results of the conductivity measurement showed that the ion concentration increased in the concentrate and decreased in the permate in the case of $100 \mathrm{~nm}$ and $5 \mathrm{~nm}$ membranes.

Inverse behavior was detected with the $5 \mathrm{kDa}$ UF membrane because in this section the permeate had higher conductivity, i.e. ion concentration due to washing out of the ions, mostly monovalent by diafiltration (Román, 2010). Overall it can be concluded that this technology is suitable to reduce the ion concentration in milk, keeping the other main components (protein, 
lactose, fat) concentrations near to the initial levels, detecting approximately less than $10 \%$ losses of the above mentioned components.

\section{Acknowledgements}

This work was partially funded by the Food Science Doctoral School of Szent István University. The Project is supported by the European Union and co-financed by the European Social Fund (grant agreement no. EFOP3.6.3-VEKOP-16-2017-00005).

\section{References}

Baker, L.A., Martin, C. (2007) Nanotechnology in biology and medicine: Methods, devices and applications. Nanomedicine: Nanotechnology, Biology and Medicine 9: 124.

Csapo, J., Csapone, K. Zs. (2002) The function of milk and dairy products in the nutrition (in Hungarian). Mezőgazda Kiadó, Budapest, ISBN 9639358681

Csighy, A. (2015) Tehéntej részleges sómentesitése komplex membránszürésieljárások alkalmazásával (In Hungarian), MSc thesis, Corvinus University of Budapest, Faculty of Food Science.

Csighy, A., Koris, A., Nath, A., Vatai, Gy. (2016) Diafiltration based cow's milk partial demineralization - laboratory membrane filtration experiments, BiosysFoodEng 2016, 1st International Conference on Biosystems and Food Engineering, Proceedings ISBN 978-963-269-598-3

Gáspár, I. (2016) Membránmüveletek anyagátadásának intenzifikálása az élelmiszeriparban és környezetvédelemben statikus keverö alkalmazásával (In Hungarian), PhD thesis, Szent István University, Food Science Doctoral School

Hodúr, C., Kertész, Sz., Szép, A., Keszthelyi-Szabó, G., László, Zs. (2013) Modeling of membrane separation and applying combined operations at biosystems, Progress in Agricultural Engineering Sciences 9: 3-25

Mohammad, A.W., Theow, Y.H., Ang, W.L., Chung, Y.T., Oatley-Radcliffe, D.L., Hilal, N. (2015) Nanofiltration membranes review: Recent advances and future prospects. Desalination 356: 226-254

Mulder, M. (1996) Basic principles of membrane technology (2 ed.). Kluwer Academic, Dordrecht, ISBN 0-7923-4248-8.

Nath, A., Szécsi, G., Csehi, B., Mednyánszky, Z., Kiskó, G., Bányai, É., Dernovicsm M.,Koris, A., (2017) Production of Hypoallergenic Antibacterial Peptides from Defatted Soybean meal by a Membrane associated bioreactor: A Bioprocess Engineering Study with Comprehensive Product Characterization, Food technol. Biotechnol, Vol: 55(3) pp. 308-324

Prudencio, E.S, Müller, C.M.O., Fritzen-Freire, C.B, Amboni, R.D.M.C., Petrus, J.C.C. (2014) Effect of whey nanofiltration process combined with diafiltration on the 
rheological and physicochemcical properties of ricotta cheese. Food Res. Int. 56: 9299

Román, A. (2010) Tejsavó nano- és diaszürésének vizsgálata (In Hungarian), PhD thesis, Corvinus University of Budapest, Food Science Doctoral School

Strathmann, H., Giorno, L., Drioli, E. (2006) An introduction to membrane science and technology. Roma: Consiglio Nazionale delle Ricerche

Suárez, E., Lobo, A., Alvarez, S., Riera, F.A., Álvarez, R. (2009) Demineralization of whey and milk ultrafiltration permeate by means of nanofiltration. Desalination 241(1-3): 272-280. 